\title{
Kristendom og naturalisme
}

\author{
Niels Henrik Gregersen
}

Dette temanummer er en lille frugt af det arbejde, der er blevet gennemført ved Centre for Naturalism and Christian Semantics ved Københavns Universitet i perioden 2008-2013. Som et såkaldt "centre of excellence" har projektet haft tre formål. Det første formål var at etablere en historisk gennemlysning af forholdet mellem stoicismen og den tidlige kristendom - fra Paulus og Johannes og frem til 200-tallet. Det andet hovedformål var at undersøge, hvilken rolle naturalismen spiller inden for nutidens teologi og filosofi, både inden for området "religion og naturvidenskab" og i forhold til nyere fænomenologi. Endelig var det centrets tredje formål at undersøge, hvad systematikere kan lære af eksegeter, der studerer den tidlige kristendom, og omvendt.

Tesen i det historiske projekt var, at stoicismen har haft en betydeligt stærkere indflydelse på Paulus- og Johanneslitteraturen end den platonisme, der først for alvor satte sig igennem i løbet af 200-tallet af den tidlige kristendom. Som bekendt er det ikke mindst centrets leder, Troels Engberg-Pedersen, der har gjort dette synspunkt gældende vedr. Paulus, efterfulgt af Gitte Buch-Hansens studie om de stoiske forudsætninger for Johannesevangeliets pneumatologi. ${ }^{1}$ Begge er repræsenteret i dette temanummer. Gennem sin tiltrædelsesforelæsning som professor mso i Ny Testamente viser Gitte Buch-Hansen, hvor afgørende en rolle antikkens biologiske tækning har haft for tolkningen af Paulus' tale om dåb og genealogi - og for kønstænkningen frem til i dag. For er det her Aristoteles' patrilinære forståelse af manden (Kristus) som det formskabende princip, der står i centrum, eller er der snarere tale om en overførsel af social og åndelig $\mathrm{kraft}-\mathrm{i}$ lighed med en adoptionsproces? I sit bidrag forholder Troels Engberg-Pedersen sig eksplicit til den tredje bjælke i centrets formål. Den sammenkobling mellem et stoisk verdensbillede og kristen tænkning, som viser sig hos Paulus, kan ifølge Engberg-Pedersen ikke

1. Troels Engberg-Pedersen, Cosmology and Self in the Apostle Paul. The Material Spirit (Oxford: Oxford University Press 2010); Gitte Buch-Hansen, 'It is the Spirit That Gives Life.' A Stoic Understanding of Pneuma in John's Gospel. BZNW 173 (Berlin: De Gruyter 2010). 
bruges som en model for, hvordan man skal forstå religion og kristendom i dag. Her må teologien udfoldes som en etik uden ontologi, der dog må gøre det forståeligt, hvorfor vi religiøst må tale i personlige kategorier om det, som vi ikke har i vores egen magt.

Herudover bringer nummeret to bidrag fra den systematiske teologi. René Rosfort spørger, hvordan kristendommens etik med dens universalisme og frihedstanke må forstås i med- og modspil til både den strenge og de mere pragmatiske versioner af naturalismen. Johanne Stubbe Teglbjærg Kristensen argumenter tilsvarende for, hvorfor dogmatikken ikke kan undvære naturalismen, fordi også kristendommen forstår mennesket som natur, men alligevel må overskride den, fordi kristendommen samtidig gør et førstepersonsperspektiv gældende, som problematiserer opfattelsen af naturalismen som en sluttet verdensopfattelse. ${ }^{2}$

Centret valgte for sit arbejde paraplybetegnelserne "naturalisme" og "kristen semantik". Betegnelsen "kristen semantik" er måske den mest usædvanlige, og derfor mest iøjnefaldende. Helt generelt betegner semantik læren om betydning i kommunikationsprocesser, og med "kristen semantik" menes ganske enkelt den betydningsverden, som kommer frem i det kristne sprog, når dette sprog anvendes $\mathrm{i}$ praktiske og sociale sammenhænge som fx dåb, nadver, bøn og tekstlæsning eller kombineres på nye måder af teologer, der forsøger at give en repræsentativ tolkning af den kristne tradition i hver deres samtid. Kristendommens semantik er således knyttet til dens pragmatik, dens brug. For så vidt omfatter den kristne semantik både noget uden for sproget, som det kristne sprog henviser til (denotationen), såvel som de forskellige sproglige tydninger og medbetydninger, som der associeres til (konnotationerne). Mens nogle former for semiotik har $ø$ nsket at blænde af for omverdensforholdet for at undersøge sprogets indre sammenhænge, har det været centrets ønske at sætte fokus på netop de praktiske og omverdensrelaterede aspekter af den kristne tradition.

Når vi har valgt at undersøge kristendommens semantikker, skyldes det også, at selvom kristendommen altid har været tænkt inden for rammen af en række verdensbilleder, indeholder kristendommen næppe selv en helt bestemt kosmologi. Verdensbilleder er noget, som enhver tids kristendom låner fra sin omverden - nærmere bestemt fra

2. Se også Giovanni Stanghellini and René Rosfort, Emotions and Personhood: Exploring Fragility - Making Sense of Vulnerability. International Perspectives in Philosophy and Psychiatry (Oxford: Oxford University Press 2013); Johanne Stubbe Teglbjærg Kristensen, Body and Hope: A Constructive Interpretation of Recent Eschatology by Means of the Phenomenology of the Body. Dogmatik in der Moderne (Tübingen: Mohr-Siebeck 2013). 
dem, der véd mere om, hvordan verden hænger sammen og "virker", end teologerne selv. Sådan var det i antikken, og sådan har det været op gennem historien, hvor kristendommen har forstået sig selv indenfor geocentriske, heliocentriske, relativitetsteoretiske og evolutionsteoretiske verdensbilleder. Tilsvarende forudsætter kristendommens tale om Gud som skaber og mennesker som skabninger ikke bestemte ontologiske opdelinger som fx modstillingen af "natur versus kultur" - eller den i naturalismen ofte forekommende modstilling af "natur versus overnatur".

Også materielle objekter og relationer indgår i en symbolsk kommunikation, hvor noget (1) betyder noget (2) for nogen (3) i en bestemt kontekst. Et slips er et stykke stof, men nok så vigtigt er det, at det bruges som et klædestykke. Og får man et slips som gave, er denne gave også noget symbolsk. Gaven er en til-gift i forhold til det blot og bart givne. På samme måde er barnets fødsel en helt igennem naturlig proces. Men i kristen semantik betegner fødslen samtidig en ny skabelse af en unik person, der står i en særlig relation til andre mennesker og til Gud. Denne semantik spiller en afgørende rolle i dåbshandlingens pragmatik, hvor barnet siges at blive indlemmet $\mathrm{i}$ Kristi legeme og dermed i menigheden. Barnets fødsel opfattes som en gave og dåben som en adoption, hvad også Gitte Buch-Hansen gør gældende i sin artikel.

Spørgsmålet er så, hvor langt kristendommens meningsuniverser lader sig "naturalisere" gennem videnskabelige forklaringsmodeller. Man kan tænke på ambitiøse bogtitler som Daniel C. Dennetts Consciousness Explained (1991), Dan Sperbers Explaining Culture (1996) eller Pascal Boyers Religion Explained (2001). På Centret har vi sat os ind $\mathrm{i}$ disse diskussioner og har også publiceret herom. Men på tværs af forskergruppens meget forskellige teologiske og filosofiske udgangspunkter, har vi været enige om, at disse naturaliseringsforsøg ikke har vist sig i stand til at levere den lovede vare. I særdeles mente vi, at generelle forklaringer - hvor vigtige de end kan være for orienteringens skyld - ikke er i stand til at indfange de væsentlige semantiske forskelle, som det er de humanistiske og teologiske fags særlige opgave at reflektere over. Hvorfor lige netop treenighedslæren, hvis ellers kognitionsforskere har ret $\mathrm{i}$, at mennesker er indrettet på at tænke "supranaturalistisk" om Gud som en separat entitet uden for verden? Og hvorfor buddhismen, når fx Det Rene Lands buddhisme hævder, at der ikke kan være en absolut modstilling mellem et menneskes natur og den såkaldte buddha-natur? Sådanne spørgsmål synes naturalistiske teorier ikke velegnede til at besvare, heller ikke de kognitionsteorier, der opererer med en fast defineret afgrænsning mellem naturlige og overnaturlige "agenter". 
Enhver forklaring synes at have sit naturlige domæne ved at kunne forklare noget, men ikke andet. Selv fysikken, der per definition omfatter "det hele", er ikke i stand til at forklare makrobiologien, endsige hvad der finder sted mellem mennesker. Dermed er heller ikke naturalismen uden videre, hvad den var engang. Nye begreber som emergens og irreducérbar kompleksitet bliver byggestene i et naturalistisk verdensbillede, der ikke længere er "rent" fysisk eller "rent" biologisk. Men det er fortsat naturalismens definerende påstand, at mennesket og dets kulturer selv er eksemplificeringer af den komplekse natur. Der findes ingen sjæl eller ånd løsgjort fra materien, endsige nogen Gud udover naturen. Dermed udgør naturalismen en særlig udfordring for enhver monoteistisk tænkning, der ser Gud som skaber af alt, som er til og vil blive til.

Ikke desto mindre findes der et forbavsende spektrum af typer af naturalisme, som hver især har et forskelligt forhold til talen om Gud. ${ }^{3}$ Der findes, hvad allerede filosoffen P.F. Strawson har kaldt en "hård naturalisme", der hævder, at alle kvalitative træk ved tilværelsen som $\mathrm{fx}$ farver, former og sprog kan tilbageføres til naturvidenskabelige entiteter. Denne videnskabelige naturalisme var særlig stærk i perioden mellem 1950'erne og 1990'erne og blev formuleret af W.V. Quine i dennes berømt-berygtede motto: "philosophy of science is philosophy enough". ${ }^{4}$ Hermed afvistes enhver mulighed for en firstphilosophy - hvad enten det var i form af fænomenologi, hermeneutik eller dagligsprogfilosofi. Hermed afvistes naturligvis også enhver teologi i gængs forstand.

Denne strenge videnskabelige naturalisme har de sidste 15-20 år været omstridt. Ganske vist findes der fortsat appeller til tanken om videnskaberne som de eneste sikre kilder til erkendelse inden for den populariserende del af naturvidenskaben, og også blandt fagfilosoffer har scientific naturalism sine fortalere. Men tesen om videnskaberne som den eneste kilde til viden om verden har vist sig vanskelig at fastholde. Der er for det første problemet med selv-reference: selv de stærkeste fortalere for en strengt videnskabelig naturalisme benytter sig af almene filosofiske argumenter, herunder common sense-eksempler, tankeeksperimenter etc. For det andet er der tolkningsproblemet: der går ikke nogen lige vej fra naturvidenskab til verdensbillede, men der vil altid foretages ontologiske spring fra metodisk begrænsede stu-

3. Centret har også været involveret i redaktionen af temanummeret "Naturalism" i det nye tidskrift Philosophy, Theology, and the Sciences 1:1 (April 2014), udgivet på forlaget Mohr-Siebeck, hvor de forskellige typer af naturalisme brydes med hinanden og udsættes for kritik.

4. Willard Van Orman Quine, "Mr, Strawson on Logical Theory”, Mind 62:248 (1953), 433-451 (446). 
dier til generelle metafysiske udsagn. For det tredje hersker der også i videnskaberne en kognitiv pluralisme: de faktiske naturvidenskaber lader sig ikke skrive sammen til én enhedsvidenskabelig beskrivelse af verden. For det fjerde har vi det førnævnte ekstensivitetsproblem: der er grænser for, hvad videnskabelige forklaringer kan "naturalisere" på overbevisende måde. Endelig er der store grundlagsproblemer, hvad angår fundamentale begreber såsom materien og de evige naturlove, som den strenge naturalisme traditionelt har forudsat. Disse begreber viser sig uhyre vanskelige at definere præcist. Hvad gør man fx, når materiebegrebet udvides i forlængelse af moderne kosmologi, hvor "mørkt stof" og endda "mørk energi" viser sig at udgøre op mod 94 \% af universets masse/energi? Og hvad gør man, når nyere fysikere, biologer og informationsteoretikere gør gældende, at information er lige så fundamental som masse/energi, når det drejer sig om kausalitet og virkekraft?' I begge tilfælde viser det gængse materiebegreb sig at være vanskeligt at få greb om. Selv Bertrand Russell måtte omkring 1920 erkende, at det ikke længere er muligt at være materialist i den gamle betydning af ordet. Den opfattelse, at den fysiske verden består af små ting, der kan lokaliseres i tid og rum, og som hen ad vejen sættes sammen ligesom Lego-klodser, styret af evige naturlove, er ikke længere holdbar.

Der er derfor ikke noget at sige til, at de fleste naturalister i dag er tilhængere af en "blød" og mere fleksibel naturalisme: liberal naturalism. Nogle ønsker at give psykologien og socialvidenskaberne samme privilegerede position som fysikken og biokemien, når det drejer sig om at forstå verdens indretninger. Andre ønsker også at give plads til før-videnskabelige forståelsesformer, så længe de holder sig til et immanent perspektiv og ikke privilegerer intuitioner o.l. Denne liberale form for naturalisme mener dog fortsat, at alt er baseret på naturlige processer, og at der ikke findes noget "overnaturligt" (såsom Gud, ånder og sjæle). De fleste er endda fortsat af den opfattelse, at naturen er fuldstændig styret af lovmæssigheder, selvom vi ikke ved hvordan. Udsagnet: "Alt er natur, og naturen er alt", fastholdes som et sekulært dogme.

Og så dog alligevel. Nogle naturalister åbner for muligheden af en matematisk platonisme, altså for den opfattelse, at matematiske relationer og possibilia muligvis er mere fundamentale end de materielle realiseringer heraf. Den liberale naturalisme viser sig også at indeholde et bredere spektrum af syn på religion og kristendom end almindeligvis antaget. Der skal ikke herske tvivl om, at den store majoritet

5. Tesen om informationens primat gøres gældende i Paul Davies \& Niels Henrik Gregersen (red.), Information and the Nature of Reality: From Physics to Metaphysics (Cambridge: Cambridge University Press 2010). 
af naturalister forstår sig som regelrette ateister. Det er så at sige den naturalistiske baggrundsantagelse, som også med jævne mellemrum luftes som selve definitionen på, hvad naturalisme er. ${ }^{6}$ Dermed har naturalismen - uanset om den er blød eller hård - imidlertid skaffet sig det problem på halsen, at den kun lader sig definere ud fra det, som den ikke er, uden egentlig at kunne sige, hvad den er. Appellen til naturalisme fungerer dermed i praksis som en diskussionsstopper.

En tredje mulighed er overhovedet at undlade en ontologisk definition af naturalismen. Det kaldes ofte en "metodisk naturalisme", men kunne måske bedre kaldes empirical naturalism. Denne holder sig til den videnskabeligt tilgængelige erfaring, uden dermed at prætendere at vide, hvad der måtte findes eller ikke findes uden for videnskabens domæne. ${ }^{7}$ Hermed falder spørgsmålet om Gud uden for videnskabens område. Dette er antageligt den mest udbredte opfattelse blandt videnskabens praktikere, i hvert fald i en europæisk kontekst.

Men der findes også dem, der ønsker at formulere en religiøs livsforståelse inden for naturalismens ontologiske rammebetingelser. De kalder sig ofte "religiøse naturalister". ${ }^{8}$ Nogle ønsker at forstå religion som en slags spiritualitet uden Gud, mens andre foreslår, at "Gud" - $\mathrm{i}$ betydningen "det guddommelige" - kan bruges som et prædikat, der kan være til hjælp, når fx tilværelsens storhed eller mening skal udtrykkes. ${ }^{9}$ Men der findes også dem, der inden for en naturalistisk referenceramme ønsker at tale om Gud som tilværelsens skænkende grund, som man blot ikke må gøre sig personalistiske afbilleder af. Her bliver Gud set som tilværelsens dybeste grund, der åbenbarer

6. Således fx. Mario De Caro \& David MacArthur, "Science, Naturalism, and the Problem of Normativity", Naturalism and Normativity (New York: Columbia University Press 2010), 1-19: "What makes Scientific Naturalism and Liberal Naturalism both versions of naturalism is that neither countenances the supernatural, whether in the form of entities (such as God, spirits, or Cartesian minds), events (such as miracles or magic), or epistemic faculties (such as mystical insights or spiritual intuition)" (3).

7. Elliott Sober, "Why Methodological Naturalism". In Biological Evolution - Facts and Theories: A Critical Appraisal 150 Years after The Origin of Species, eds. G. Aulette, M. LeClerc, and R. Martinez, 359-378 (Rome: Gregorian Biblical Press 2011). 8. Se analysen hos Mikael Stenmark, "Religious Naturalism and Its Rivals", Religious Studies 49:4 (2013), 529-550.

9. I The Really Hard Problem. Meaning in a Material World. (Cambridge, Mass.: MIT Press 2007) taler Owen Flanagan fx om den evt. nytte af en "ekspressivistisk" gudstro i modsætning til et "assertiv" tro: "Expressivist theism says what it says in a manner that recognizes itself, and conveys forthrightly that it is simply telling a story where (a) one is 'wanted' and can come in handy for certain purposes (giving the youth some understanding of the complex texture of things), and (b) might do some good for those who want a story that makes the universe seem purposeful and not absurd, not an inexplicable given"(197). - Dette er et eksempel på den form for pragmatisme, som René Rosfort vender sig imod i sin artikel. 
sig som et nærvær midt i tilværelsens ellers normale hændelser. "Are we Producers or Samplers of Presence?", spørger Princeton-filosoffen Mark Johnston. Hans svar er, at vi er doubly donatory beings, der har fået en dobbelt gave: Vi er kommet gratis ind i verden, og hér, midt i verden, åbner der sig en række gaver fra den Gud, der skænker sig selv. ${ }^{10}$

En tredje mulighed bygger på en forståelse af Gud som uendelighed snarere end som en afsondret entitet. Denne opfattelse ligger i forlængelse af kirkefaderen Gregor af Nyssas filosofiske teologi og findes i moderne tid videreført ikke bare hos G.W.F. Hegel, men også fx hos Karl Jaspers, for hvem Gud er das Umgreifende, eller hos en teolog som Wolfhart Pannenberg. Her er Gud som uendeligheden den, der omfatter endeligheden i sig selv. Derfor giver det ikke mening at tale om Gud som en adskilt "overnatur" uden for verden. Denne sidste model følger naturalismens påstand, at alting hænger sammen og udgør et hele. For os mennesker er det ikke muligt at tale om Guds natur uden om Guds aktivitet i verden. Af samme grund lader det sig ikke gøre at opdele virkeligheden i to dele, en rent "naturlig" og en rent "overnaturlig". Dette uendeligheds-baserede gudsbegreb adskiller sig fra de gængse former for naturalisme derved, at naturen ikke er den sidste realitet, men derimod er en sat eller skabt realitet. Her bliver naturalismen sat ind $i$ en teologisk referenceramme, snarere end at gudsbegrebet søges placeret inden for en forud-etableret naturalistisk forklaringsramme. ${ }^{11}$

Sprogligt oversat kunne man sige, at i den første model er "gud" eller det guddommelige at forstå som et adjektiv - en beskrivelse, der tillægges en i sig selv meningsløs verden for at artikulere menneskets iboende behov for at finde mening $\mathrm{i}$ et ufølsomt univers, hvor sådan noget som mening faktisk slet ikke findes. Efter den anden model er "Gud" sprogligt set ligesom det ultimative subjekt, der er tilværelsens kilde på godt og ondt - men selv står hinsides godt og ondt. Set herudfra drejer det sig derfor om at redde Gud fra den tendens til antropomorfisme, der udspringer af menneskets illusion om, at verden vil føje sig efter menneskets egocentriske behov. Ifølge den tredje model har "Gud" derimod en funktion ligesom et hebraisk verbum, der i sig

10. Mark Johnston, Saving God: Religion after Idolatry (Princeton: Princeton University Press 2009), 132. Johnston definerer Gud som følger: "The Highest One = the outpouring of Existence Itself by way of its exemplification in ordinary existents for the sake of the self-disclosure of Existence Itself” $(2009,116)$. Denne væsentlige bog, der advokerer for en panenteisme (i modsætning til en panteisme), har spillet en væsentlig rolle $\mathrm{i}$ centrets diskussioner.

11. Dette er undertegnedes position, se "Naturalism in the Mirror of Religion: Three Theological Options", Philosophy, Theology and the Sciences 1:1 (2014), 99129. 
både bærer det handlende subjekt (Gud selv) og resultatet af Guds handlen (naturen og historien). Ligesom i ground of being-teologien er Gud her forstået som tilværelsens yderste begyndelse og kilde. Men til forskel herfra er det i det uendelighedsbaserede gudsbegreb pointen, at ikke alt, som sker i naturens verden, uden videre åbenbarer, hvad eller hvem Gud er. Et centralt religiøst begreb som "åbenbaring” tjener netop til at identificere, hvem den Gud er, der er til stede midt i naturens ambivalenser. Som den uendelige er Gud allestedsnærværende, men ikke allestedsmanifest.

Som man vil se, har vi på Centre for Naturalism and Christian Semantics udarbejdet forskellige løsningsforslag inden for det spektrum af muligheder, som ligger i forholdet mellem kristendom og naturalisme. Det er denne overordnede problemstilling, der har bundet os sammen i et arbejdsfællesskab. 